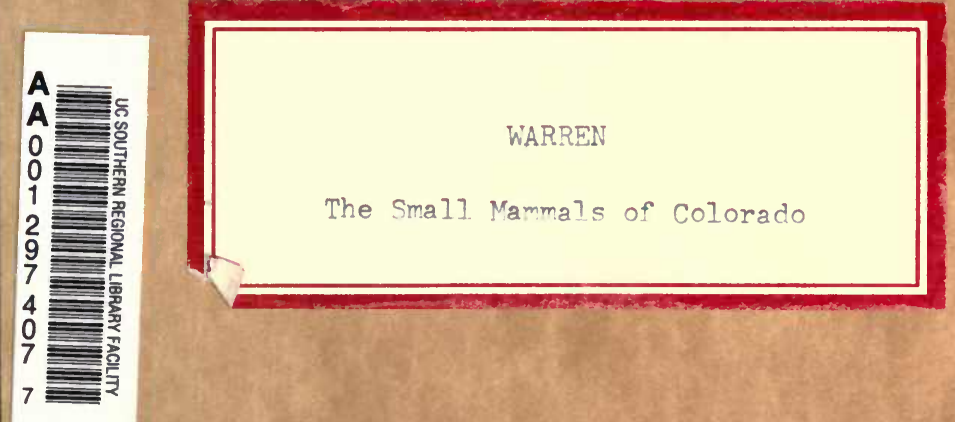

QL

719

C 6 W 25 


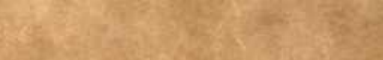

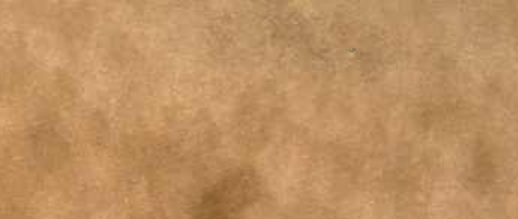

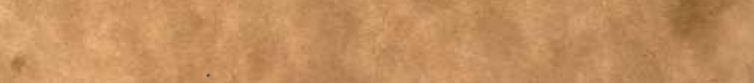

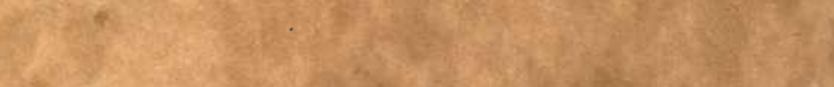

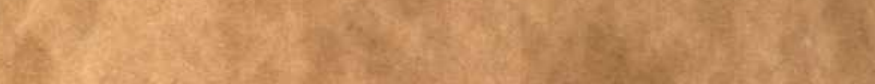

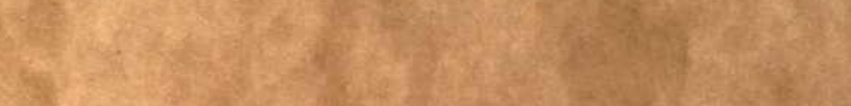

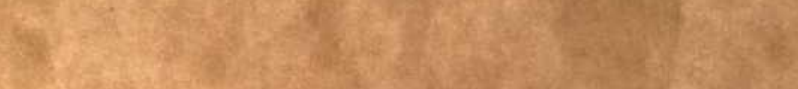

1.03

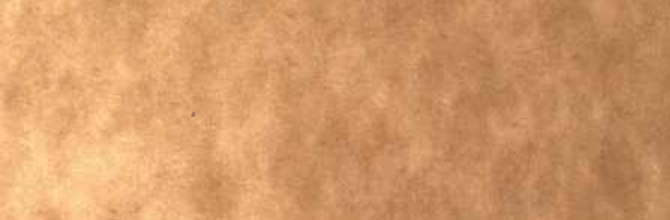

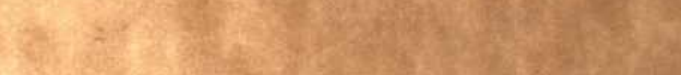

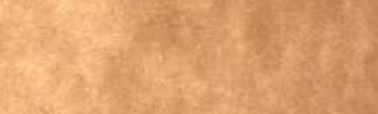

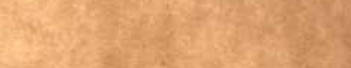

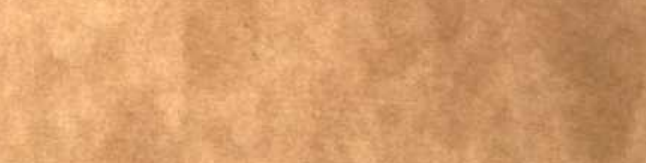

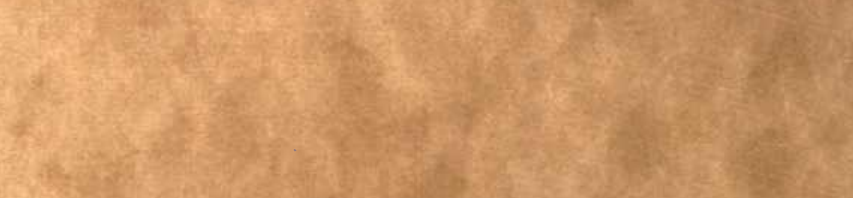

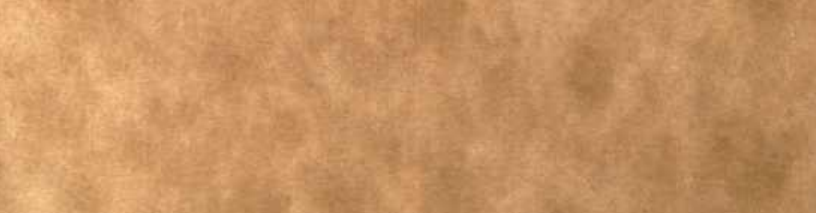

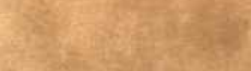

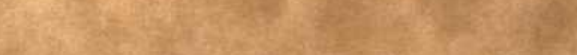

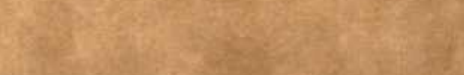

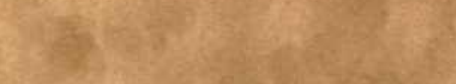




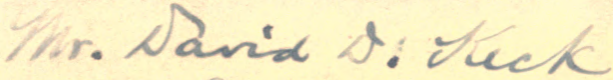

\title{
Small Mammals of Colorado
}

\author{
By \\ EDWARD ROYAL WARREN, S. B.
}

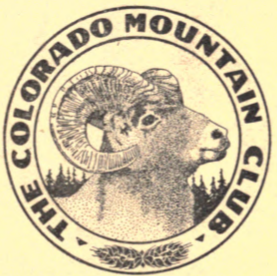

ILLUSTRATED

Published by

THE COLORADO MOUNTAIN CLUB June, 1921

George H. Harvey, Jr..............President 3120 West Twenty-third Avenue, Denver.

George C. Barnard.............Vice President 615 Seventeenth Street, Denver.

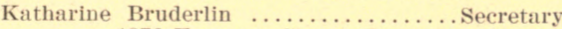
1276 Emerson Street, Denver.

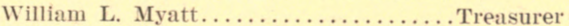
3053 West Twenty-ninth Avenue, Denver.

Publication No. 7

Price: 25 Cents 



\section{The \\ Small Mammals of Colorado}

By

EDWARD ROYAL, WARREN, S. B.

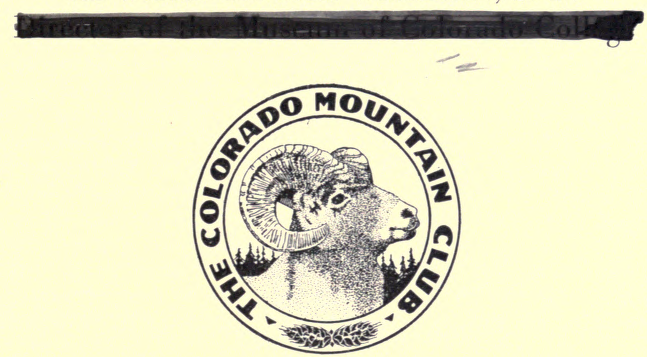

ILLUSTRATED

\section{Publi-hed by \\ THE COLORADO MOUNTAIN CLUB June, 1921}

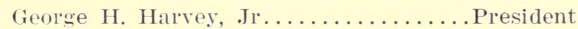

3120 West Twenty-third Avenue, Denver.

George C. Barnard..............Vice President 615 Seventeenth Street, Denver.

Katharine Bruderlin .............................. 1276 Emerson Street, Denver.

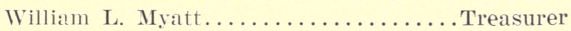
3053 West Twenty-ninth Avenue, Denver.

Publication No. 7

Price: 25 Cents 
COPYRIGHT, 1921.

BY THE

COLORADO MOUNTAIN CLUB. 


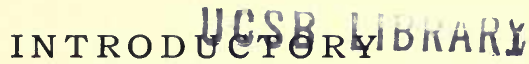

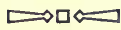

$\mathrm{T}$

HIS bulletin on the small manmals of Colorado omits all mention of

the tree squirrels, ground squirrels, chipmunks, and gophers, which were excellently treated by $\mathrm{Mr}$. Robert Rockwell in his bulletin on those animals. The present paper aims to give some mention of our smaller mammals, though it has been a little difficult at times to tell where to draw the line, and what to include and what to omit. Many of these animals are but little known to the casual observer, largely because of the nocturnal habits of the majority of the species, and the retiring habits of others. When one becomes acquainted with them and their ways he finds them very interesting, and their iffe histories well worth studying. In fact there is still much to be learned about many of them.

Since the writer's "The Mammals of Colorado" was published, some ten years ago, a number of the genera of North American mammals have been studied by specialists, with the result that some species and subspecies have been added to and others dropped from our local list, and some of the scientific names have been changed. While not making the latter especially prominent in the text, they have invariably been given, for they are a more positive identification of the species than any English or vernacular names. No detailed descriptions of any of the species are included, only a general idea of the color and size is given. The total length is from the end of the nose to the end of the tail, measured in a straight line when the animal is stretched out, and the tail is measured irom the root to the tip.

I have omitted all mention of the bats, although a considerable number of species is found in the State. These belong to so many different genera that a general description of the animals would be very unsatisfactory, and a detailed account is somewhat beyond the scope of this paper.

For interesting and authoritative accounts of the habits of many of our small manmals I would refer my readers to "The Wild Animals of North America," by E. W. Nelson, Chief of the U. S. Biological Survey, published by the National Geographic Society. Mr. Nelson's opportunities of observing the habits of many of our species have been remarkable, and he has made much use of the work of other naturalists.

In giving scientific names, when the name of a genus is repeated it is not given in full but abbreviated to the initial letter; likewise in the case of repetition of specific names.

Unless otherwise mentioned, the illustrations are from my own photographs. Nos. $1,2,3,4,6,7,8,10,11,13,14,15,16,18$ and 20 were originally published in the "Mammals of Colorado" and are printed from the cuts used in that book. For several of the illustrations which have not hitherto been published, I wish to acknowledge my indebtedness to $\mathrm{Mr}$. Charles Mace, Mr. Clark Blickensderfer, Mr. Albert Haanstad, and the Colorado Agricultural College through Mr. W. L. Burnett.

The pictures will doubtless be of as much use as the text in showing what the animals are like.

E. R. W. 



\section{The Small Mammals of Colorado}

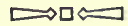

MOLES ANI) SHREWS.

Our single species of mole is confined to the northeastern portion of Colorado, indeed the only record of which I have knowledge is from Wray. This species is the Northern Plains Mole, Scalopus aquaticus caryi. In "The Mammals of Colorado" it is called the Large-nosed or Western silvery Mole. Both moles and shrews belong to the order Insectivora, the members of which depend largely upon insects and similar forms of animal life for their subsistence.

Of exclusively underground habits, moles are rarely seen on the surrace of the ground, though they make their presence known by the mounds of earth which they throw up from their tunnels. These tunnels are made in their search for food, which consists of earthworms and grubs. The torelegs are short, with wide, naked hands, the palms being turned outward, and forming splendid instruments for digging. The velvety fur almost hides the eye. This fur is brown, with grayish shades, lighter below, appearing dull or bright and silvery according as the light strikes the hair. Moleskins are used as fur, being very soft and warm, though it takes many to make a garment.

The small animals known as Shrews are often confused with mice, to which they are not at all nearly related, belonging, as previously stated, to the Insectivora, while mice are rodents, or gnawers. Four of our Colorado species are tiny brown animals about four inches long, of which the tail comprises somewhat less than half. They live about the damp meadows in the mountains, along the streams, and also among the dead logs and underbrush in the timber, and range to timberline, and even to the summit of Pikes Peak. They make much use of meadow mice runways, and are often captured in traps set in such places. Voracious little animals, with sharp teeth and savage dispositions, they have no hesitation in attacking prey as large as themselves. If two are confined together one usually kills and eats the other, and they are said to occasionally kill mice. The eyes

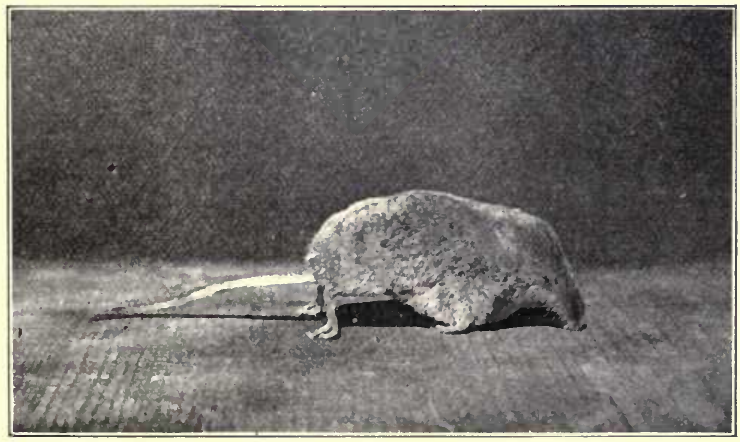

No. 1. Dusky Shrew, sorex obseurus; photographed from a dead specimen. 
are very small, and doubtless the sight is poor and the animal much dependent on the flexible, sensitive snout to aid it in its activities. Shrews are about both by day and by night.

The four species of small shrews in Colorado are the Masked Shrew, Sorex personatus, Dobson's Shrew, Sorex vagrans dobsoni, Dusky Shrew, Sorex obscurus, and the Dwarf Shrew, Sorex tencllus nanus.

Besides these small shrews there is a larger species, the Water Shrew, Neosorcx navigator, about the size of our common deer mice. It is a handsome little animal, with close, soft, glossy fur of a plumbeous color, mixed with hoary above and silvery white below. It is found along the mountain streams, more especially at the higher altitudes, ranging from 7,000 to over 10,000 feet. Its food habits are much the same as those of the small species.

\section{RING-TAIL.}

The Ring-Tail, known to the Mexicans as "Cacomixtle", and also called "Civet Cat", a name to which it has exactly as much right as the Spotted Skunk has-which is none at all-is an inhabitant of the lower portions of southwestern Colorado, and has been taken as high as 6,800 feet, though its usual range is no doubt much lower than that. It is a pretty little animal, about 29 inches long, the tail being about half of the total length. Buff mixed with black is the body color, and the tail is ringed alternately with black and white and has a white tip.

Really closely allied to the raccoon, it is like that animal in being a somewhat indiscriminate feeder, eating rats, mice, and other small mammals, birds, insects, and at times fruits and berries. It is strictly nocturnal. Miners and others sometimes make pets of these animals, and find them very interesting. The scientific name is Bassariscus astutus.

\section{MARTEN.}

The Pine or Rocky Mountain Marten, Martes caurina origenes, is confined to the heavy spruce timber of the highest mountains and is rather lare, being irregularly distributed through its range. It leads to a great extent an arboreal life, being as much at home in a tree as a squirrel. It is a handsome animal with its brown coat and fine soft fur, which always brings a good price. The throat is yellow and orange from the chin to between the forelegs, this varying much in different individuals. Like other weasels, it lives on rats, mice, squirrels and birds. The young are born early in spring, and are about six to the litter, the nests being in hollow trees, under fallen timber, and in holes in the ground.

\section{WOLVERENE.}

Wolverenes (Gulo luscus) are very rare animals in Colorado, and are confined to the higher portions of the timber in the mountains. It is seldom one hears of the animal, and it is often found on enquiring that it is unknown in the locality. It is a powerfully built creature, about forty inches long, of which the tail comprises ten inches. The stout, heavy-set body and short legs with long, sharp claws make an effective combination for the destructive work of which the animal is capable, and with which it is credited in the northern regions, such as destroying traps, and caches of food and supplies. The color is dark brown above, and lighter along the sides and beneath. The fur has considerable value. The young are born about June and are from one to three in a litter.

\section{WEASELS.}

For real bloodthirstiness the Weasels probably come as near deserving the palm as any group of mammals. Certainly they are wicked little beasts, and courageous too, for they will put up a fight against enemies 
many times their size. The Marten and Wolverene are also weasels, though of larger size than the species to which the term is restricted in popular parlance. Of the four species of weasel found in Colorado, three have a white winter coat and a brown summer coat, the fourth, the Blackfooted Ferret (Mustela nigripes), keeps its yellowish brown coat the year round. The first three species are the Long-tailed Weasel, Mustela Iongicauda, Mountain Weasel, Mustela arizonensis, and the Dwarf Weasel, Mustela streatori leptus, the first-named being the largest, and an inhabitant of the plains, while the other two live in the foothills and mountains. While the Ferret is 19 to 20 inches long the Dwarf Weasel is about $91 / 2$ inches in length.

The Ferret was discovered by Audubon and described by him, and then no additional specimens were seen by naturalists for so many years that it came to be regarded almost as a myth. It is, however, pretty well distributed over the plains region, though nowhere common, and in Colorado occurs in South Park, and possibly in our other high parks. It is addicted to living about the prairie dog towns, where it preys on the inhabitants.

Weasels live on mice, chipmunks, ground and tree squirrels, and birds when they can catch them. Once when I was riding up a steep mountain trail a chipmunk came running down the hill before me and turned up the trail, squealing all the time as if in mortal terror, for which there seemed ample reason when a moment later a weasel came along, nose to the ground, following the chipmunk's trail. It stopped a second or two to look at me, then went on, and I doubt not that soon a chipmunk came to an untimely end.

Weasels have rather large families, six or eight in a litter, once a year, and no doubt the parents have to rustle hard to provide food for the hungry mouths. They destroy many mice, and no doubt as a rule they are beneficial rather than otherwise.

All weasels are provided with scent bags near the rectum and, though small, if one is cut open the odor is very penetrating and almost overpowering.

\section{MIN.}

Minks are weasels leading a semiaquatic life, and are somewhat larger than the Black-footed Ferret, being about two feet long. Their brown fur has always been in demand, and brings a good price; it is not only a handsome fur, but a very durable one, wearing well for many years. Mink are probably found along all the streams which contain food for them, both on the plains and in the mountains. Fish are eaten, as well as mice, squirrels and birds. They are not too particular, so long as it is flesh and they capture it themselves, or if they can steal it from the captor, as they will fish if left where it is accessible. Occasionally a Mink makes a raid on a poultry yard with destructive results. The home is in a hole near the water, and doubtless muskrat burrows are often occupied.

\section{SkUNKS.}

These malodorous animals are represented in Colorado by species belonging to two different genera, the large skunks with white stripes on the back, belonging to the genus Mephitis, and the smaller spotted skunks belonging to the genus spilogale. There are two species of the large skunks in Colorado, the Northern Plains Skunk (Mephitis hudsonica), and the Long-tailed Texas Skunk (Mephitis mesomelas varians). The latter is probably the most widely distributed of the two, but skunks are found all over the state, going to at least 10,000 feet, at which altitude in Gunnison county I once had the pleasure of inhaling the perfume of one in March 
when the snow was five feet deep, but did not see the animal itself, and knew not what stirred it up.

These animals are not at all particular as to their diet. They eat

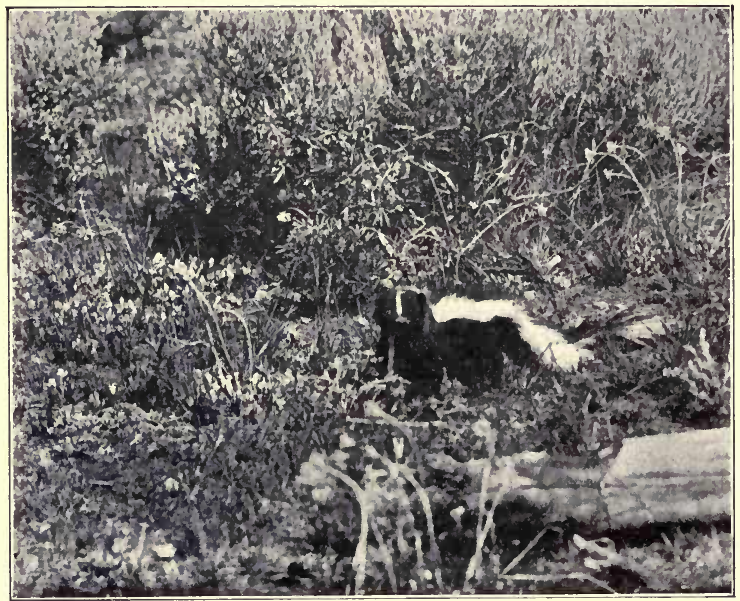

No. 2. Long-tailed Texas Skunk, Mephitis mesomelas varlans.

mice and any other small animals which come their way. Ground-nesting birds and their eggs suffer, while grubs and grasshoppers are eaten in large numbers. I think at times they must largely subsist on these latter insects. Take it all around, skunks are really useful. They are prolific breeders, six or eight young in a litter.

Recently, when furs were at the top prices, the best black skunk skins were quoted at figures once applicable to far more valuable furs. It is a really good and durable fur, however, wearing very well indeed.

\section{SPOTTED SKUNKS.}

These pretty little skunks furnish the fur known to the trade as "Civet," a name properly belonging to a quite different animal. There are four species of these skunks found in Colorado, the Prairie Spotted Skunk, Spilogale interrupta, Arizona Spotted Skunk, Spilogale arizonae, Rocky Mountain Spotted Skunk, Spilogale tenuis, and the Great Basin Spotted Skunk, Spilogale gracilis saxatilis. These skunks do not range so high in the mountains as their larger relatives, 8,000 feet probably being their limit in altitude. Below this they appear to be pretty generally distributed over the state. While there is a general similarity in the habits of both groups, the small ones are more lightly built and active and even to some extent climb into trees and bushes. In many parts of the West they are called "Hydrophobia Skunks" or "Phoby Cats". There is a somewhat universal impression that their bite always causes hydrophobia and is invariably fatal. A. H. Howell of the U. S. Biological Survey says in this connection: "While there are a few authentic cases of skunk bite having resulted fatally there are also many instances in which it has produced no 
ill effects whatever. The recorded cases of skunk rabies are nearly all from the plains region of the west (Kansas, Texas, and Arizona) and relate more to Mephitis than to spilogale. The most plausible explanation of these facts seems to be that at certain periods rabies may become locally epidemic among dogs and wolves, and by them be communicated to skunks."

I recall a somewhat amusing incident in this connection. I was in western Gunnison county on a surveying expedition, having a couple of men along. A deer had been killed after arriving at camp and was hanging up close to our beds. I slept with one of the men. Toward daylight I was awakened by his making a sudden movement and exclaiming very emphatically "Get out of here". I said, "What's the matter, Henry?" Henry looked rather foolish, and said, "Oh, nothing." Next morning he told me that a skunk had been poking about after scraps of meat, and he was afraid it might bite him, so had thrown his hat at it. Fortunately nothing disagreeable had happened, but I suggested he would better not be so impulsive next time.

Neither of the skunks has many enemies besides man, though the Great Horned Owl does kill and eat them, thereby rendering its plumage distinctly odoriferous.

The stripes and spots on the small species make a decidedly effective fur and it is in considerable demand.

\section{HOG-NOSED OR WHITE-BACKED SKCNK.}

While the manuscript of this bulletin was in course of preparation Mr. C. E. Aiken of Colorado Springs called the writer's attention to a skunk which had heen brought to him for mounting. It was immediately recognized as a Hog-nosed or White-backed Skunk, belonging to the genus Conepatus, a Middle and South American group, ranging as far north as Albuquerque, New Mexico; at least this was the northernmost record until the above-mentioned specimen was secured on Little Fountain Creek, southwest from Colorado Springs. The Biological Survey refers it provisionally to Mearns' Skunk, Conepatus mesoleucus mearnsi. These animals are distinguished by having the nose prolonged into a naked, somewhat piglike snout, a single broad white stripe on back and tail, and very long, strong claws on the fore feet. They subsist very largely on grubs and insects which they dig from the ground with their claws or root up with the nose. This sudden and unexpected discovery raises the question whether this species has been hitherto overlooked, or whether one or more individuals may have wandered north far from the usual range. I should bo pleased to hear from anyone knowing of similar occurrences in Colorado.

\section{BAI)(iER.}

The Badger is a rather unnecessarily maligned animal. True, it does dig big holes in the ground into which a horse may thrust a leg, giving its rider a bad fall and possibly also breaking the leg in the hole, but the chances are that the hole was dug in order to get a prairie dog for dinner, so that the Badger had a really good excuse for digging. As a matter of fact badgers are quite useful animals, destroying many prairie dogs, ground squirrels and similar vermin. Their powerful forelegs and paws armed with long stout claws are efficient tools for excavating, and the flattened, coinpressible body is excellently adapted for underground work, while the heavy cuat of long, coarse hair protects the body from dirt and dampness. Badgers range all over Colorado, living both on the plains and in the mountains, even up to timberline.

I once saw a badger traveling along after a couple of coyotes. A friend 
has told me of a similar instance, and Thompson Seton makes mention of another. The object of the association is unknown. Can any of my readers offer any information, or give any further occurrences of this

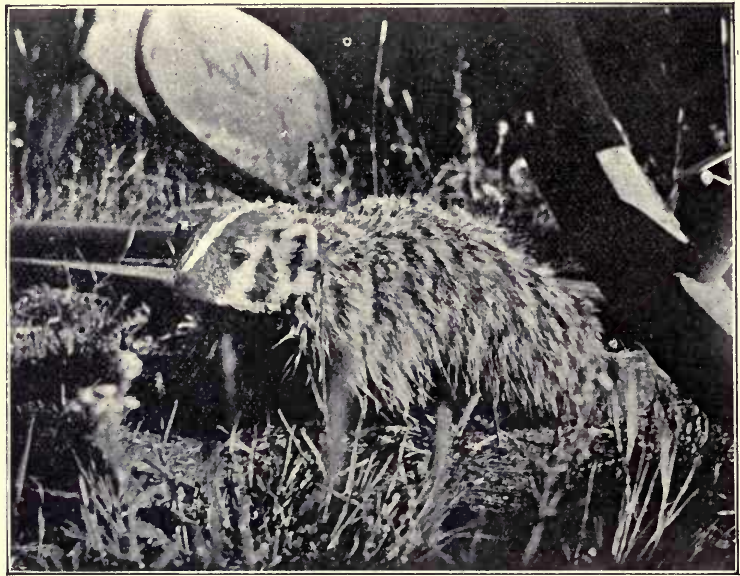

No. 3. Badger, Taxidea taxus.

nature? Badgers are too often killed at sight, which is to be deplored, for they are too useful to be destroyed. While the fur has a certain value it is hardly enough to make it worth while to kill them merely for that. The scientific name is Taxidea taxus. Mr. J. D. Figgins has recently described a subspecies, Phipps' Badger, 'T. t. phippsi, from southwestern Colorado.

Leaving the carnivorous animals which have just been described we come to the rodents, which group comprises by far the larger number of the mammals to which we apply the term "small". They are easily identified by the large incisor teeth, two each in the upper and lower jaws. Rabbits, while they also have long incisors, have four in the upper jaw, a small pair behind the large front ones, and because of this and other structural differences are now placed, together with the conies, in a separate order, the Lagomorpha, which means literally having the form of a hare.

\section{GRASSHOPPER MICE.}

The first of the rodents on our list are the Grasshopper Mice, or Scorpion Mice as they are sometimes called, belonging to the genus Onychomys, which is corfined to western North America, ranging from the plains of Alberta, Saskatchewan and Manitoba, south to central Mexico. and east to western Minnesota and eastern Kansas. These animals are 
near relatives of the deer mice, but are easily distinguished from the latter by their heavy bodies, short tails and usually paler colors. They are dwellers in the open country, never, to the best of my knowledge, found in underbrush or about rocky places. They live largely, if not entirely, in holes in the ground, sometinies in holes abandoned by other animals, such as prairie dogs, for I have taken them at the old burrows; and they may dig homes for themselves, as they have good, strong fore paws and claws and are often taken at small holes on the prairie. As might be inferred from the names, they eat animal as well as vegetable food, destroy a good many insects such as grasshoppers and beetles, and are called "Scorpion Mice" because they eat scorpions when found. One which I kept in confinement for a short time preferred raw meat to any of the vegetable foods I offered it. Their animal diet causes them to decompose much more rapidly after death than mice which feed mainly on vegetable matter. They have a considerable range in altitude, being found from the lowest elevations in the state to as high as 8,500 feet in North Park.

The species are all bicolored, the under parts and feet being white, while the color of the upper parts in adults of course varies in different species, but is generally some tawny color, occasionally quite reddish in individuals. The young, as in the case of the deer mice, are blue or mouse gray in color, gaining the adult colors with maturity. They breed in spring and summer, having from three to six young in a litter, four probably being the average number.

The body is stout and heavily built, and while the total length is about the same as that of the deer mice inhabiting the same regions, the Grasshopper Mice look larger because of the proportionately shorter tail. The total length is six inches or a trifle less, and the tail 1.7 inches.

In Colorado we have two species or rather subspecies of these animals, Seton's Grasshopper Mouse, Onychomys leucogaster arcticeps, and the Black-browed Grasshopper Mouse, Onychomys lencogaster melanophrys, the two having separate distributions, but together inhabiting most of the open prairie and park country of the state, and, as before stated, attaining an altitude of 8,500 feet in North Park.

\section{HARVEST MCL.}

The Harvest Mice, whose generic name is Rheithrodontomys, are small animals inhabiting in North America the two Sonoran zones. East of the Mississippi river they do not occur north of the Ohio and Potomac valleys, whereas in the western United States they range into North Dakota, Montana and Washington, and southward through Mexico and Central America to Panama. In Mexico and Central America the genus ranges from the tropical zone at or near sea level through all the zones to and including the Canadian at timberline. Howell, in a recent revision of the genus, recognizes fifty-eight forms, of which four are found in Colorado.

The members of this genus can always be recognized by the upper incisors each having a longitudinal groove. This groove is very fine and one sometimes has to look quite closely to find it. While they have a superficial resemblance to the deer mice, they are smaller in size, with proportionately longer tails, which are slender, scaly, and thinly haired. 'The ears are prominent.

Our Harvest Mice are dwellers in the open, preferring places overgrown with grass or weeds. One of the Colorado species, the Pallid Harvest Mouse, is found only in dry, sandy uplands. In the dry western regions these mice in general are apt to frequent the grassy borders of sloughs, small streams, and irrigation ditches. The nests are built of grass, lined with soft materials, and placed either on the ground, or above it in bushes 
or low trees. They travel in runways of their own, and also in those made by other mice, and are out both by day and night. The food is mainly seeds and grain, with some green vegetation. The young are four or more in number, and they appear to breed throughout spring and summer into the fall.

Cary noted one at Wray moving about in the brush and often winding its tail around a twig to assist itself. The writer found one at Barr under an old piece of sheet iron lying on the prairie.

The colors of the various forms in Colorado vary from light buff to various shades of brown, usually light, but often, if not always, mixed with blackish hairs. The tail is bicolor, brown above, lighter or white below. Adults vary in length from 4.8 to 5.95 inches, and the tail from 2 to 2.5 inches.

The Harvest Mice occurring in Colorado are the Pallid Harvest Mouse, Rheithrodontomys albescens albescens; the San Luis Valley or Mountain Harvest Mouse, Ir. montanus; the Aztec Harvest Mouse, Rheithrodontomys megalotis aztecus; and the Prairie or Nebraska Harvest Mouse, IR. m. dychei.

The Mountain Harvest Mouse is interesting from the fact that the first specimen was taken by one of the Pacific Railroad surveying parties in August, 1853, and was described by Baird in 1855. The type specimen long remained unique. A single immature specimen was taken by Vernon Bailey at Del Norte in 1904 . In the fall of 1907 Merritt Cary went to the Medano Ranch, 15 miles northeast of Mosca, probably not far from the place at which the type was taken, and collected a considerable series of the animals, enabling a detailed study to be made for the first time. He found them on a low sandy ridge running through the meadows on the ranch. The present writer was unable to secure any at the same place two years later, but did take one at Crestone, several miles farther north.

As a whole the distribution of Harvest Mice in Colorado is not very well known. They seem to be quite common in northeastern Colorado, have been taken at Cañon City, and are also found in various portions of southwestern Colorado. I have not found them at Colorado Springs, nor did I take any in southeastern Colorado in 1905.

\section{DEER MICE OR WHITE-FOOTED MICE.}

Of our native wild mice probably the best known to outers are those belonging to the group collectlvely known as Deer Mice or White-footed Mice, the former name being derived from the tawny color of many of the species, something like that of the red coat of a deer, and the latter from the fact that most of them have white feet. They are members of the genus Peromyscus, a very large group which has been subdivided into several subgenera. In Colorado we have no less than eight species and subspecies.

There is more or less similarity in the habits of all these. They are strictly nocturnal. It would be difficult to find a locality or situation which was not inhabited by one or more species. In certain portions of Colorado I have found four species in the same locality. They are sure to be found about rocks, and dead logs and brush. The banks of the dry arroyos of the prairies often have holes inhabited by these mice. Traps set in meadow mice runways in wet grassy places usually yield their quota of deer mice. In short, they are practically everywhere. In altitude they range from the lowest elevations up to timberline at least. Osgood says: "Throughout practically all of the western United States they exist in countless numbers, perhaps exceeding those of the other combined mammalian inhabitants of the region."

Usually, so far as my observations go, living in holes in the ground 
or about rocks and logs, they will occasionally make their nests of grass and other soft materials under boards or pieces of sheet iron lying on the ground. In places where the common house mouse is not found they

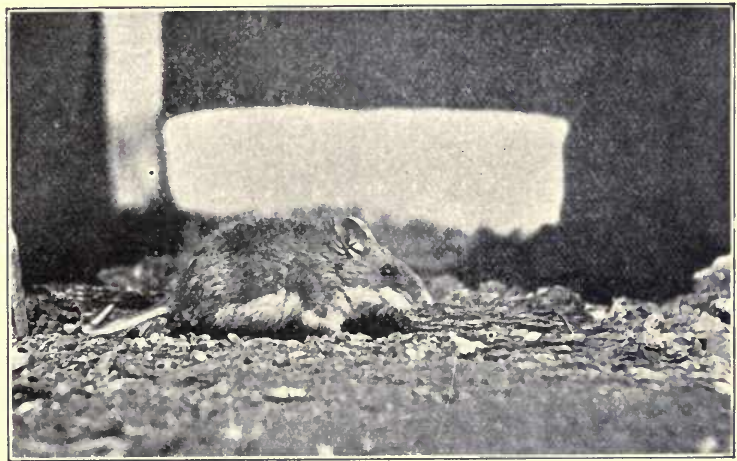

No. 4. Tawny Deer-mouse, Peromyseus m. rufinus.

often come into houses and other buildings and act much as the latter does. From my bed I have seen mice running about the floor of a log cabin. The least movement and away they scampered.

Their food consists of almost anything, I think. Seeds and berries of all sorts, and meat is also eaten. They nibble about dead carcasses, and

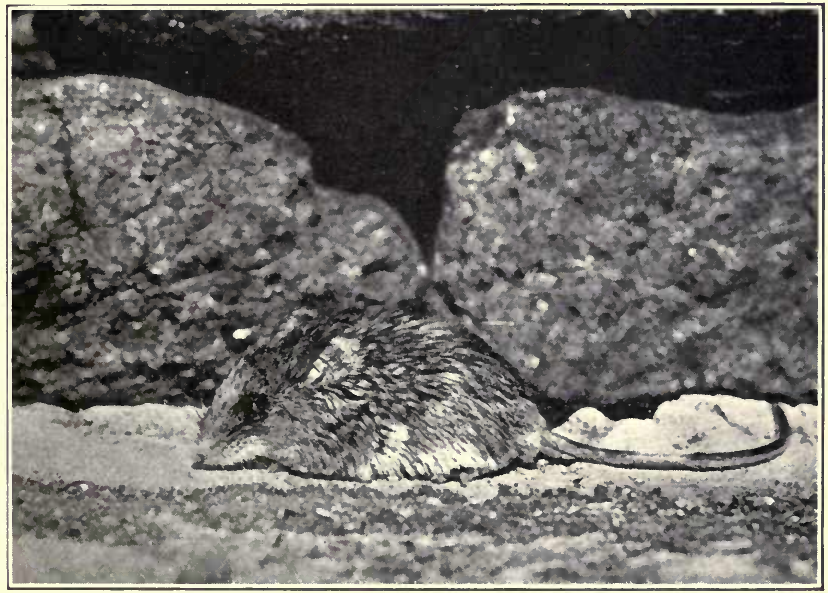

No. 5. I tong-nosed Deer-mouse, I'romyseus nasutus. 
when several are confined together in a cage, they are sometimes, but not always, cannibalistic enough to eat their own kind. Grain is sometimes carried away from the farmers' stacks, and because of their large numbers they may do considerable damage.

The first coat of the young is a bluish gray in color, quite different from that of the adult, which is not attained until the animal is full grown, or nearly so.

Some of our species are about the size of the common house mouse, others are noticeably larger. The smaller species have a total length of six inches, including the tail, which is 2.6 inches, and our largest species is 7.5 inches long, half of which is included in the tail. Our eight species may be divided into two groups, one of which we will call the small-eared group, and the other the big-eared group. The species belonging to the former are the Tawny Deer Mouse, Peromyscus maniculatus rufinus; the Nebraska or Black-eared Deer Mouse, P. m. osgoodi; the Yellow Deer Mouse, P. m. nebrascensis; and the Tornillo Deer Mouse, P. leucopus tornillo. The big-eared species are the Golden-breasted Deer Mouse or Buffbreasted Cañon Mouse, P. crinitus auripectus; Rowley's Deer Mouse, P. boylci rowleyi; True's Deer Mouse, P. truei; and the Long-nosed Deer Mouse or Estes Park Cliff Mouse, P. nasutus.

The mice of this latter group appear to make their homes more exclusively about rocky places than those of the first group. Thus, in southwest Colorado I found the Tawny, Rowley's, the Golden-breasted and True's Deer Mice all living among the rocks in a cañon of the Dolores river, but only the first-named was taken elsewhere, as for instance out in the sage brush and greasewood, and this has been my experience in other localities.

\section{WOOD RATS.}

Most of us Colorado people have met with Mountain Rats, Wood Rats, Pack Rats, or Trade Rats, as they are variously termed, for one species or another is found over the whole area of the state, though in some of the eastern counties they are very locally distributed because of the lack of country preferred by them. There are in all ten species and subspecies of these animals found in Colorado, six belonging to the roundtailed group and four to the bushy-tailed group. They all belong to the genus Neotoma, the bushy-tailed animals being placed in the subgenus Teonoma, while the round-tailed belong to the subgenus Neotoma.

The genus, with six other allied genera, belongs to the subfamily Neotomina, which is confined to North and Middle America, from Nicaragua and Guatemala northward into Alaska and northern Canada to latitude $62^{\circ}$, and in the southern United States from the Atlantic to the Pacific. There are no other animals in this state with which any of the species is likely to be confused, unless it be the common brown rat, and the naked tail of this animal at once suffices to distinguish it, as the tails of our native species are all haired, while none of them are at all like the brown rat in color.

The various Wood Rats have at least one habit in common, no matter where they may happen to live, and this is the accumulation of piles of trash and rubbish about their nests, or nest sites when the nests happen to be in holes. These accumulations are also placed away from the nests at times. It is the habit of carrying away articles of all sorts which has given these animals the names of "Pack Rats" and "Trade Rats", the latter because of a myth that something is left in exchange for what is taken. Where there are rocks the nests are in holes or crevices, but the pile of trash is ever present, and it is also there 
when, as is sometimes the case, the nest is in a hollow tree. Some of the species make nests under bushes or tree cactus, piling a heap of stuff over tile nest. It would be easier to say what is not in these heaps

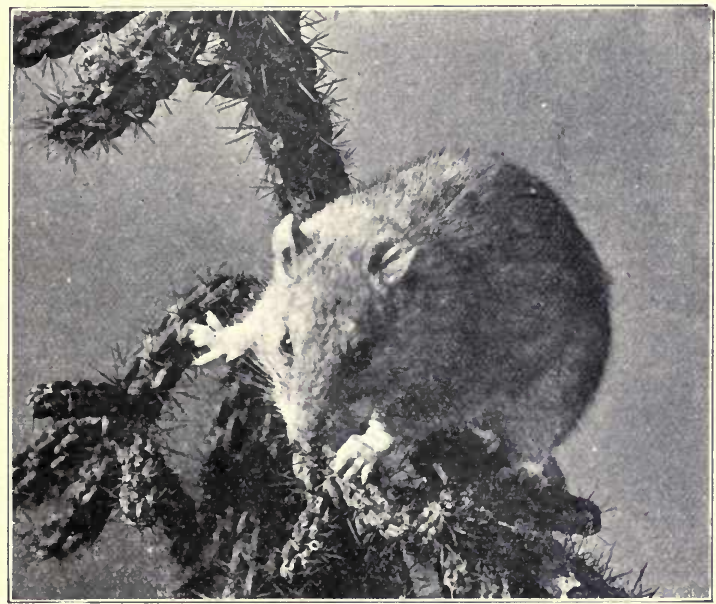

No, 6. Bailey's Wood-rat on tree cactus, veotoma r. Daileyi. Photosraph by Herman W. Nash.

than what is, for anything portable is carried to them, sticks, bones, cow chips, horse dung, pieces of metal, rags, anything not too much for the animal's strength. Nor do the animals always take their booty to the nests. A lot of knives, forks and spoons were once missed from a mine

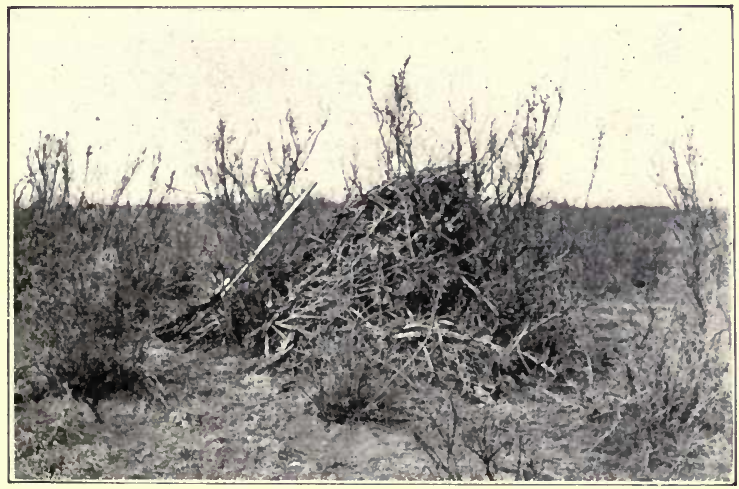

No. 7. Nest of Pailey's Wood-rat. Photograph by Herman W. Nash. 
cabin which had been unoccupied all winter, and were found under the floor, but not at a nest. Another rat industriously carried chips from a wood pile into a blacksmith shop and dropped them into a barrel standing

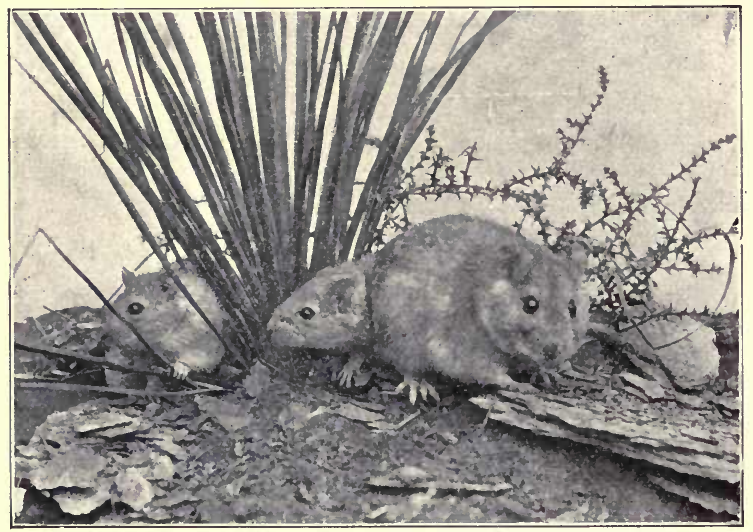

No. 8. Bailey's Wood-rat, female with two young. Photograph by Herman W. Nash.

there. The surroundings of the nests always appear decidedly untidy because of the rubbish piles and the dung of the owners scattered about, though it is said that the nests themselves are always clean and tidy.

All the species are usually nocturnal, but they may occasionally be seen in the daytime. Their food is mainly of a vegetable nature, though they will occasionally eat flesh. All sorts of fruits, seeds, berries and nuts are eaten, and no doubt such insects as may be captured are deroured.

I think but one litter of young in a season is the rule for our species. The offspring are born late in the spring or early summer, and are from three to six in number.

Our smallest species, the Desert Wood Rat, has a total length of 11.25 inches, of which the tail occupies 4.8 inches, while the largest species, the Mountain Rat, is 15 inches or more in total length, with the tail 6.3 inches. I have measured specimens which were 18 inches over all, but these were unusually large.

The names of those of our Wood Rats included in the Round-tailed Group are as follows: Bailey's Wood Rat, Neotoma floridana baileyi; Baird's Wood Rat, N. micropns micropus; Hoary Wood Rat, N. m. canescens; Warren's White-throated Wood Rat, N. albigula warreni; Gale's or the Colorado Wood Rat, N. Mexicana fallax; and the Desert Wood Rat, N. desertorum. The Bushy-tailed Group includes: the Mountain Rat or Colorado Bushy-tailed Wood Rat, N. cinerea orolestes; the Arizona Wood Rat, N. c. arizonac: the Cinnamon Wood Rat, N. c. cinmamomca; and the Pallid Wood Rat, N. c. rup:cola.

Of our various species the Mountain Rat is perhaps the most widely distributed. Beginning with the upper foothills of the Front and Pikes Peak Ranges it extends westward through the mountains, and even down 
to such low altitudes as Grand Junction, 4,600 feet, giving one of the greatest zonal ranges of any Colorado mammal.

'This species is the Mountain Rat, I am tempted to say of fable, and

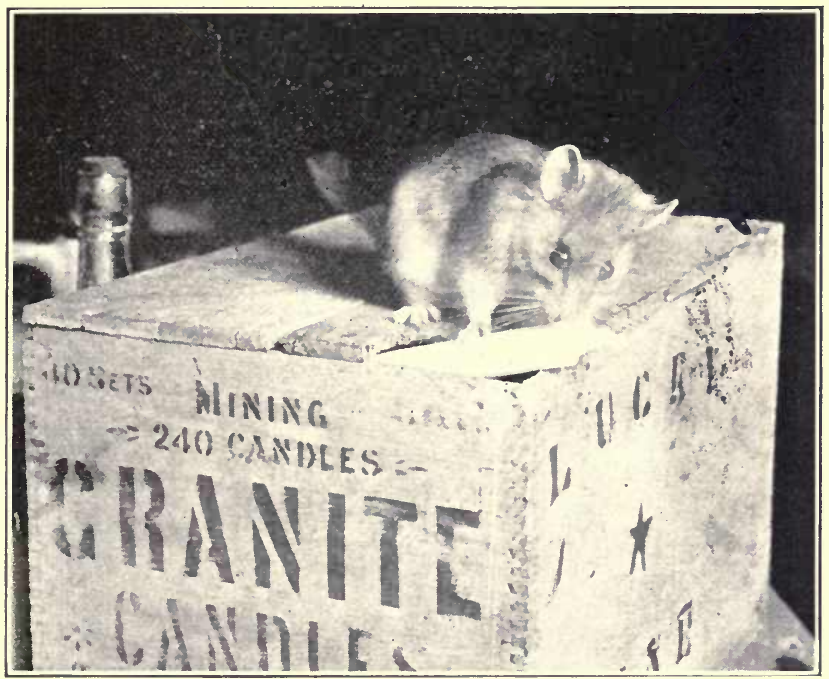

No. 9. Mountain Rat or Pack Rat, Neotoma cinerea orolestes. Photograph by Charles E. Mace.

certainly many fables have been told about the creature, which is well known to all dwellers in its range. Were you ever in a cabin or house which had a canvas or cloth ceiling, and where a rat lived? And after you had turned in did you not enjoy having that rat run foot races with himself all over that canvas, making as much racket as a four-horse team? One rat can certainly give a fellow the impression that there are a dozen of them seampering about up there. Perhaps when you roll out in the morning and pull on your shoe you find a nice chip tucked away in the toe. Merely Brother Rat's playfulness. Some of your smaller belongings may be missing and you find them elsewhere than where you left them the night before, or even do not find them at all. Your friend was very busy while you slumbered.

Wherever these rats are found they make their homes in every imaginable location. Among other places they go into abandoned mine tunnels, among the drifts and timbers. I took one in an old tunnel at Querida, Custer County, at a point 225 feet from the entrance. It is in the fall and winter that these animals are most prone to come into habitations and other bulldings, though they are just as likely to come into an empty house, a stable, or an abandoned shaft house as into an occupied dwelling. I have seen green aspen leaves in their piles in at least two cases, and actually saw a rat eating one of the leaves. At the same place were pieces of fungus from dead logs, apparently gathered for food. 


\section{MEADOW MICE OR FIELD MICE.}

The group or family of mammals known as Field Mice, Meadow Mice, or Voles is of wide distribution, being found over practically the whole of

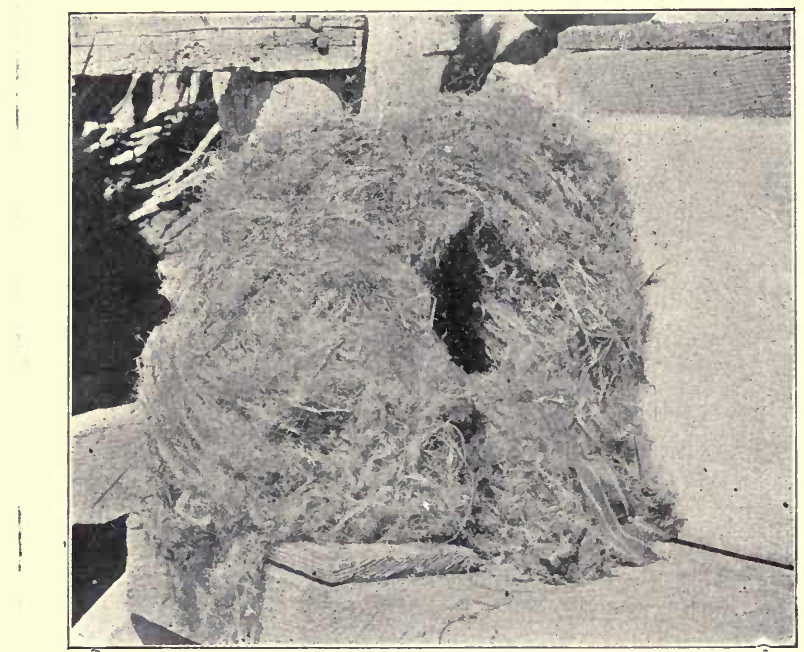

No. 10. Nest of Mountain Rat; found on sill under a building, removed to outside and placed on steps in same position with respect to the boards as in its original location; composed almost entirely of shredded gunny sacks.

the northern hemisphere outside of the tropical regions. Technically it is known as the subfamily Microtima, and it is represented in Colorado by four genera, Microtus, comprising what may for convenience be termed the true Meadow Mice; Evotomys or the Red-backed Mice; Phenacomys, the Mountain Voles or False Lemming Mice; and Fiber or Ondatra, the Muskrats.

Except the Muskrats these are all small, heavy-bodied, short-tailed animals, leading terrestrial lives in grassy places, usually damp by preference, or in the woods, among fallen logs or about the brush, and in Colorado at all elevations from the plains to above 14,000 feet. Their food is largely vegetable, consisting of grasses and other green stuff, as well as seeds and bark. It is by gnawing the bark of fruit trees that much damage to orchards is done by these mice. None of the species is known to nibernate.

Of these four genera the Muskrats are easily distinguished by their large size and general adaptation to a semiaquatic life; and the Red-backed Mice, as their name suggests, by the reddish color of the back. The two remaining genera are more difficult to distinguish from one another, and as a matter of fact the Mountain Voles were for a long time confused with the other Field Mice until Dr. C. H. Merriam discovered that their molar teeth had roots while the molars of the others were always rootless. The Colorado species of Mountain Voles have a proportionately much 
shorter tail than our various species of Field Mice, with one exception, and that one is not likely to cause any confusion.

Of this family the Field Mice have the greatest number of species in

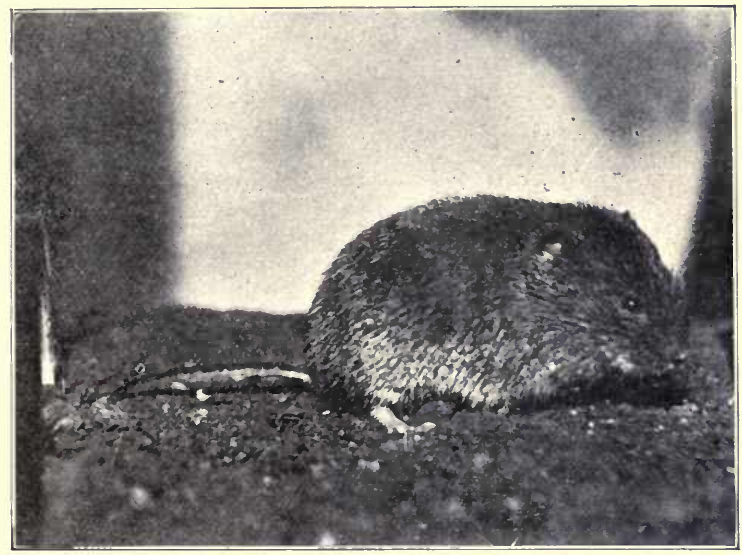

No. 11. Cantankerous Vole, Mierotus mordax; about two-thirds life size.

Colorado, namely five, and they are found almost everywhere except in the driest prairie regions. When living in grassy places they make numerous runways through the grass, along which they travel and which are utilized by the other small mammals inhabiting such places, such as deer mice and shrews. Their holes are not far from the runways, and in the burrows are globular nests of grass and other plant fibers. In addition to having holes these mice make nests on top of the ground of the same materials as the underground nests, and they also make nests under pieces of board or sheet iron which may be lying about.

The names of our Field or Meadow Mice are as follows: The Saguache Meadow Mouse, Microtus pennsylranicus molestus; the Dwarf Meadow Mouse, M. nanus; the Cantankerous or Rocky Mountain Meadow Mouse, I. morlax; the Pigmy Meadow Mouse, M. pauperrimus; and Hayden's Meadow Mouse or Upland Mouse, M. ochrogaster haydeni.

\section{RED-BACKEI) MICI.}

The Red-backed Mice, genus Evotomys, are, as previously stated, distinguished from the other Colorado meadow mice by the reddish color of the back. The genus is circumpolar in distribution, and ranges little, if any, below the Canadian Zone. The species found in Colorado is the Colorado Red-backed Mouse, Evotomys gapperi galei.

In Colorado 8,000 feet is about the lowest altitude to which this species ranges. Whether it is to be found above timberline I cannot say as there are no records bearing upon this point, but it is confined to the boreal zones. It lives in the woods and is found about the fallen logs, making its nests both under logs and in burrows. It does not hibernate and is not known to lay up any stores of food for winter use. Its food is seeds of 
yarious sorts, also grass. From four to six young are born in a litter, and the breeding season extends from May into July.

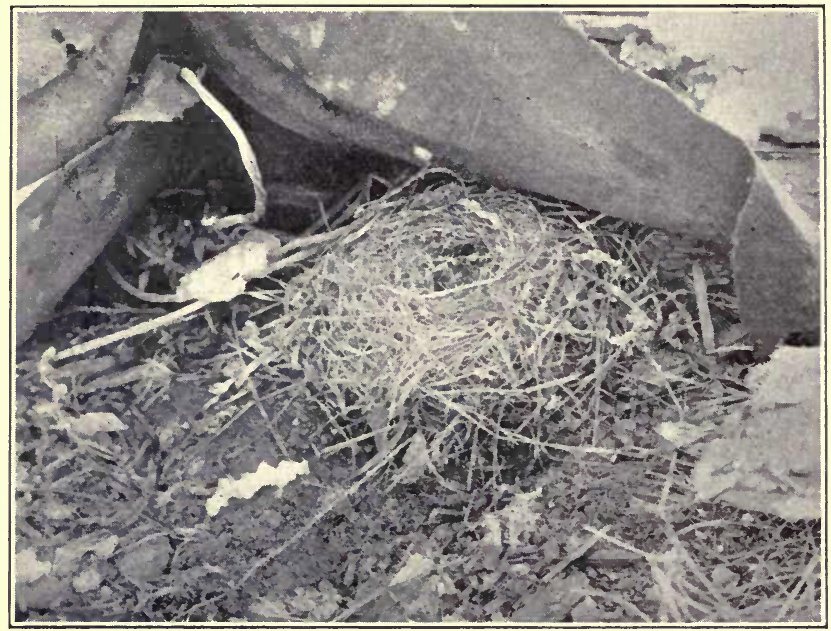

No. 12. Nest of Colorado Red-backed Mouse, Evotomys gapperi galei; on ground under piece of building paper. Photograph by Albert Haanstad.

\section{MOUNTAIN LEMMING MICE OR VOLES.}

It is difficult so to describe the Mountain Voles that a layman can rlistinguish them from the true Neadow Mice. They are small animals with proportionately shorter tails than most of our species of Meadow Mice. The most certain distinguishing characteristic is the molar teeth, vach of which has two roots in the adult animals, while the molar teetl of the Meadow Mice have no roots, the portion which is seated in the jaw being the same shape as the external portion.

The name Phenacomys means "false mouse", and was given because the members of the genus had been placed in Microtns because of their external resemblance to that genus. The genus is North American and is confined to the boreal regions of the continent and higher elevations of the Rocky and other western mountains. There are two species in Colorado, the Mountain Lemming Mouse or Idaho Mountain Vole, Phenacomys orophilus, and Preble's Lemming Mouse or Mountain Vole, P. preblei.

Vernon Bailey, in his account of the mammals of the Glacier National Park, says this species lives in burrows in the grassy parks, and makes tiny runways through the grass from one burrow to another, but both the burrows and runways are well concealed. The animals are largely nocturnal. They seer to eat much green. vegetation. The nests appear to be entirely underground. They apparently lave in a season several litters of from four to six young.

At present Preble's Mountain Vole is known only from the type local- 
ity, which is Twin or Lillie's peak, near Long's peak, at 9,000 feet, and from North Boulder creek, also at about 9,000 feet elevation. The type was taken in a perfectly dry locality covered by forest, most of which had fallen.

\section{MUSKRATS.}

The Muskrat is well adapted to the semiaquatic life which it leads, having a dense close under fur with long guard hairs which it is almost impossible to wet through, at least while the animal is alive, an almost naked tail flattened vertically, and large webbed hind feet set obliquely to the leg so that they can be turned edgewise when carried forward. The ears are small and hidden in the fur. It makes its home in holes in the banks of streams and ponds, and houses of mud and grass are also built in shallow water. Even though it is extensively trapped for its fur it is still abundant, and is almost as much so in closely settled regions as in the wilderness. At least civilization seems to have no terrors for it, and the proximity of mankind does not drive the animal away. (After I had written the preceding I learned that in Minnesota and elsewhere the catch of Muskrats had decreased greatly the last year, the decrease being apparently due to overtrapping during the period of extraordinarily high prices for furs.) The food is grass and other vegetation; we often see on the waters of ponds floating grass which these animals have cut for lood. Where fresh water mussels occur these are brought up from the bottom and opened by biting the hinge between the two valves, whereupon the contents are devoured.

While more or less of nocturnal or twilight habits the Muskrat is often seen about in the daytime, especially when not much disturbed, sometimes swimming or feeding, or sunning itself in some convenient place. Trails are often worn through the grass where the animals come up from the water or travel across from one water to another. The litters are large, up to twelve in number, and are born from May to July, and probably at least two litters in a season are the rule in Colorado.

Two species are found in Colorado, the Rocky Mountain Muskrat, Ondatra zibethicus osoyooensis, which is the Muskrat found west of the summit of the continental divide and the Sangre de Cristo Range; and the Great Plains Muskrat, O. z. cinnamominus, the species of the plains region, but ranging up the eastern slopes of the mountains as high as Ward, Boulder County. The summits of the ranges appear to form the tarlier between this and the Rocky Mountain Muskrat.

\section{POCKET MICE.}

The daintiest little animals we have are the smaller species of Pocket Mice, the bodies of some of which are hardly as large and long as two joints of one's finger, and which are clothed in a soft, silky fur. Unfortunately one seldom sees them in life as they are practically exclusively nocturnal. They have cheek pouches, or pockets with external openings, hence their name, these pouches being used for carrying food. These mice make their homes in burrows as tiny as their occupants, often about yuccas or anong low bushes, and sometimes with little trails leading from one to another. The entrances are often closed during the day. Not all these mice nuke small burrows, for the large Kansas Pocket Mouse makes a good-sized hole, often going straight down into the ground. The food consists of the seeds of any of the plants occurring in their habitat.

Pocket Mice are nocturnal in their habits. Some of the species are among our very smallest mammals. Our smaller species vary in total length from 4.5 to 5.5 inches, the tail being from 2 to 2.65 inches. The Kansas Pocket Mouse has a total length of 8.75 inches, and tail 4.25 
inches. There are six species of Pocket Mice recorded as actually having been taken in Colorado, as follows: The Buff-bellied Pocket Mouse, Perognathus fasciatus infralnteus; the Plains Pocket Mouse, P. flavescens; the Black-eared Pocket Mouse, P. apache melanotis; the Colorado Pocket Mouse, P. a. caryi; Baird's Pocket Mouse, P. flarus, and the Kansas Pocket Mouse, P. hispidus paradoxus. In color they are various shades of buff, with many black or blackish hairs mingled in the back. They are found in the prairie and other dry regions of the state.

\section{KANGAROO RATS.}

Kangaroo Rats are an exclusively western group of mammals, ranging from Oregon well south into Mexico, and always confined to more or less arid regions. Like the Pocket Mice and Pocket Gopher's they have external cheek pouches, opening on the outside of the mouth, not on the inside as in the case of the chipmunks and similar animals; these pouches are lined with hair and are used for carrying food to the nests and storage places. Their hind legs are greatly elongated, and the tail is extremely long, with a tuft or pencil at the tip, and is well-haired its full length. All the species have certain markings in common, these being more or less distinct crescentic black facial lines, white spot over eye and behind ear, and a white stripe across the thigh. The upper parts are buffy, with more or fewer black hairs; the under parts and feet white. The tail has a dark stripe above and another below, with white between. The pencil is dark. The total length is about ten inches, the tail about six.

We have four forms in Colorado, the Mountain or San Luis Kangaroo Rat, Perodipus ordii montanus; the Moki Kangaroo Rat, P. o. Iongipes; the Wyoming Kangaroo Rat, P. o. luteolus; and Richardson's Kangaroo Rat, P. o. richardsoni. They inhabit many of the lower arid portions of the state.

The habits of these animals are very interesting. While mainly twilight or nocturnal, as their large eyes would lead one to suspect, yet they do occasionally go abroad by daylight, and the individual whose picture is shown here was captured in the daytime in the San Luis Valley where it was out among the greasewood and sage brush. Two of us had no difficulty in running it down and taking it in our hands. It did not appear to leap in trying to escape, but rather to run. They live in burrows,

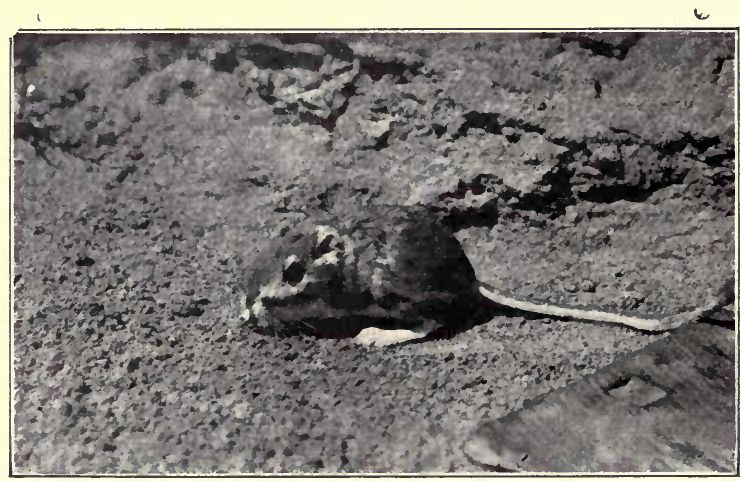

No. 13. Mountain Kangaroo Rat, Perodipus montanus. 
usually preferring sandy soil, and often throw up quite good-sized mounds, to which there are several entrances, each with a well marked trail leading from it. The entrances are often closed during the day. Frequently the holes are under a bush or yucca, and almost invariably there are two entrances, one on either side of the bush. Trails run from one bush to another, and the colony is a network of trails. I have on a few occasions dug out burrows, but without gaining much information as to the habits of the owners; but I may have been unfortunate in my choice of digging places. They are quite social and live in colonies of various sizes, a num. ber of holes being found not far apart.

The food is principally seeds of various kinds, and leaves of som: plants are also eaten. Stores are laid up in the burrows against scarcity and inclement weather, for while they do not hibernate, they may remain within doors during cold or stormy weather. The food is placed in the cheek pouches with the fore paws, used like hands. When it is desired to empty the pouches the animal puts its fore paws behind the pouches and brings then forward, pressing against the face at the same time, thuz forcing out the contents. I have seen a pocket gopher do this and the movements are very quick.

\section{JUMPING MICE.}

The Jumping Mice, which must not be confused with the Kangaroo Rats, belong to the genus Zapus, a small group which with the exception of one species is confined to North America. They are small animals, with bodies about the size of House Mice, with the hindlegs greatly elongated, and with very long tails. Of some twenty known species and subspecies two have been found in Colorado, the Prairie Jumping Mouse, Zapus ludisonius campestris, and the Rocky Mountain Jumping Mouse, Zapus princeps. The former has been found in various counties in northeastern Colorado, while the latter appears to be pretty generally distributed through the mountainous portions of the state.

The color is buff, which on the back is much darkened by blackish hairs, so that the animal appears to have a wide buff stripe on either side.

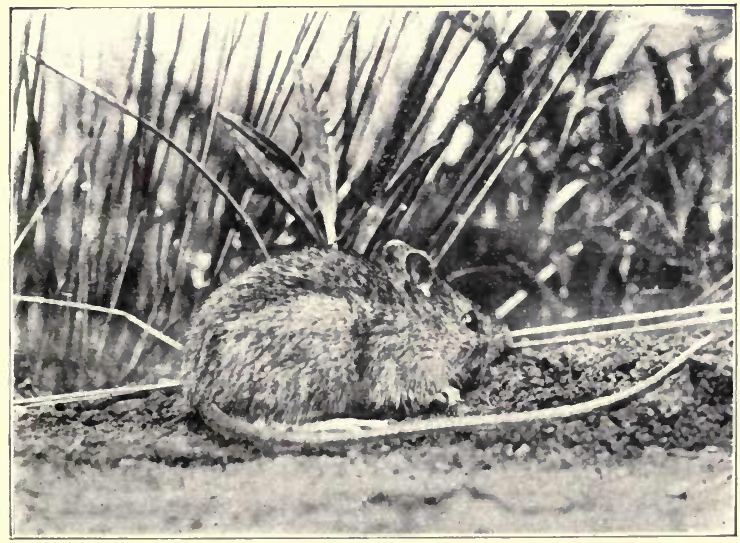

No. 14. Rocky Mountain Jumping Mouse, Zapus princeps; about half life size. 
The under parts are white with some buff. The tail is bicolor, dusky above, whitish below. The total length is about 9 inches, and tail 5.5 inches. These animals live in meadows, along the edges of woods, and in shrubby fields, showing a preference for moist places. I have taken them near streams in quite heavy timber in the mountains, and also in open ground along small spring runs. In Colorado the altitudinal range is up to above 9,000 feet. The nests are of grass, sometimes underground, sometimes above, in the grass or by small bushes. Five or six young are born in late spring or early summer. The food is seeds and similar material. They hibernate in holes underground, but may come out for a short time in mild weather.

\section{PORCUPINE.}

Yellow-haired Porcupine (Ercthizon epixanthus) is the name of our prickly friend whose work is often seen in the forests in the shape of bare spots on the trunks of trees where the bark has been gnawed away. Sometimes the trees are girdled and die, more often the bare places are scattered here and there on the tree and do no permanent harm except possibly by affording opportunities for insect enemies of the tree to begin their destructive work. With their powerful claws and limbs porcupines are excellent though usually rather slow climbers, yet can scuttle up a tree in fairly lively fashion if alarmed. The bark of trees forms their principal article of diet. They are by preference frequenters of the coniferous forests, but at times wander away and have even been captured on the plains well away from the foothills. The young are from one to four in

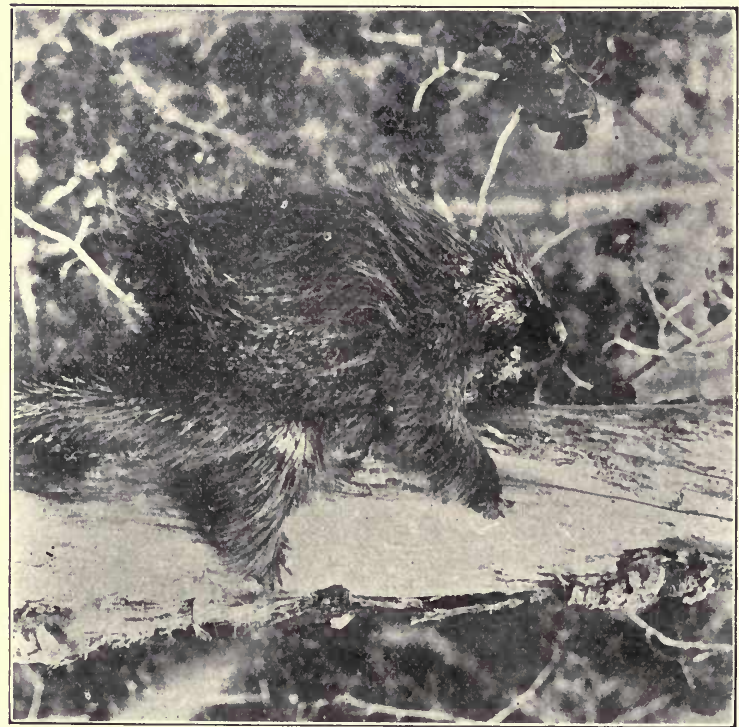

No. 15. Yellow-haired Porcupine, Erethizon epixanthum. 
number, are born with their spiny armament already developed, and are large as compared with the size of the parent.

In spite of the protecting quills some animals are brave enough or reckless enough to kill and eat porcupines. Mountain lions are said to do it, and other animals may do so. I have seen the remains of porcupines which had been killed and eaten, and evidently the victim had been turned on its back and the belly opened. Beside the damage done to trees porcupines are frequently nuisances about cabins, gnawing anything which has been handled by man, apparently attracted by the salty flavor left by perspiration, and cabin floors are often badly damaged by the powerful teeth of these animals. The flesh is palatable, or at least eatable, though personally I can plead guilty to having eaten but one, or my share thereof, a half grown animal which came about our camp at Mud Springs on White River plateau and disturbed our slumbers. As we were out of meat it was decided that a fitting punishment for the animal was for us to eat it. The llesh had a peculiar gamy flavor, different from anything I have ever tasted. Adults are about 36 inches in total length, with tail about 9 inches. They may weigh as much as 20 pounds. The quills are overlaid by long guard hairs, and have short hairs mingled with them, and are everywhere on the animal except the nose. They are very loosely held to the skin and pull out readily when the points enter some foreign body such as a dog's nose, for they are barbed and once they have penetrated are difficult to extract.

\section{MAIRMOTS OR WOODCHCCIS.}

Once we thought there was but one species of Marmot in Colorado, but an examination of series of specimens has resulted in the separation of our marmots into three forms, all subspecies of the Yellow-bellied Marmot, Marmota flaviventer. They are the Park Marmot, M. f. luteola, Warren's Marmot, M. f. warreni, and the Dusky Marmot, M. f. obscura. Mr.

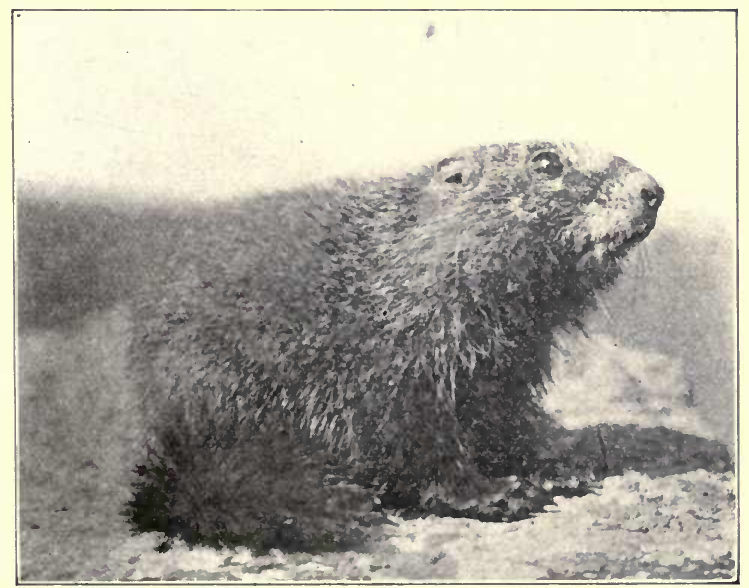

No. 16. Western Woodchuck, Marmota flaviventer; half grown young. 
J. D. Figgins has described a fourth, Campion's Marmot, M. f. campioni. The Dusky Marmot is largest and darkest. Marmots are of various shades of brown, with more or less black hairs and with white markings about the face. The total length is two feet, more or less, and the tail is 8 or 9 inches long, including the hair. In Colorado, as elsewhere, the vernacular names are Woodchuck and Groundhog. The range in altitude inhabited by these animals is considerable, as I have taken them in the White River country below 7,000 feet, and they reach the summits of the highest mountains, being reported from the top of Long's Peak.

Marmots make their homes in a variety of situations, sometimes digging their burrows in the earth on the open hillsides, but more often, I think, preferring to live about the slide rock, in which, or under which, they can excavate their homes, and which affords a refuge from their enemies. Here they lie on top of rocks which command a good view of the surrounding country, and sleep in the sun, uttering a sharp whistle of alarm when anyone comes in sight. The food is grass and presumably other plants. No stores are laid up for the winter, for that season is spent in hibernation, which begins usually in October. At that time the animals are very fat. The young, four to eight in number, are born in late spring or early summer, and may be seen out of the holes the last of June or early in July.

\section{PRAIRIE DOGS.}

Prairie Dogs are such familiar animals to most Coloradoans that it seems somewhat absurd to try to describe them in a publication of this sort. We are all acquainted with these chunky little animals, which sit on the mounds by the holes, ready to pop out of sight at the least indication of danger. However, it may be of interest to know that there are

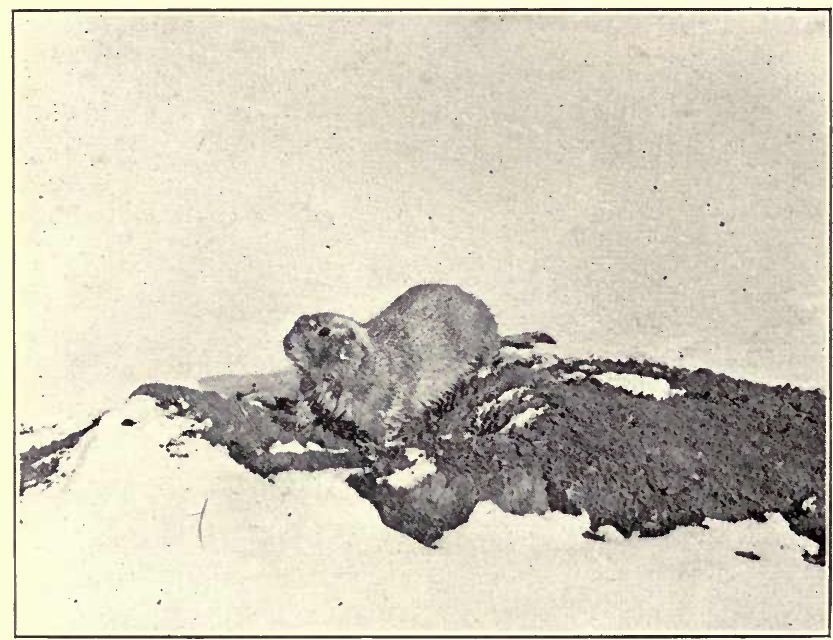

No. 17. Adult Plains Prairie Dog, Cynomys ludovicianus; in winter pelage. Photograph by Clark Blickensderfer. 
four species and subspecies of these animals in Colorado, as follows: the Plains Prairie Dog, Cynomys lndovicianus; the White-tailed Prairie Dog, C. lencurus; Gunnison's Prairie Dog, C. gunnisoni; and the Zuni Prairie Dog, C. gumnisoni zumiensis. The first named is the prairie dog of the plains region east of the foothills, and is the species which lives in the largest colonies or towns. The others are found in the large mountain parks, and in the open spaces in the western part of the state, but never living in such large towns as the preceding. The total length of an adult is from 13 to 14 inches, of which the tail occupies 2.5 to 3 inches. The color varies, naturally, in the different species, but is some shade of brown, with a certain number of black hairs intermingled. The Plains species has a black-tipped tail; the others have tails with white tips. The breeding season is in the spring, and the young are large enough to come out of the holes some time in May or early June. The Plains Prairie Dog does not hibernate, though it may, in severe winter weather, remain underground for a few days. The other species, through most of their range at least, probably spend the greater portion of the cold weather in hibernation, but they have at times been seen out in midwinter in cold weather.

These animals are of much economic importance because of their destructive habits. When living on uncultivated lands they eat the grass and other vegetation, consuming what would otherwise feed many cattle or sheep. When near farms they do great damage to crops of many sorts. Much work has been done in the way of destroying them, and by concerted action of the landowners of a region good results can be obtained and the pests kept under control. It is hardly needful to say that the good old story of the prairie dog, owl and rattlesnake living in the same hole is a myth. The two latter animals are likely to live on the prairie dogs rather than with them. The snakes, if not the owls, certainly eat the young ones. Eagles and various hawks, to say nothing of coyotes and badgers, also prey on the prairie dogs. It is not true that the dogs dig deep holes to water. Their moisture is obtained from the vegetation they eat.

\section{CONY.}

To meet these curious and interesting little cousins of the rabbits one has to seek the higher elevations and the slide rock, especially the latter, for sometimes the animals follow an unusually attractive rock slide down to a comparatively low elevation. Cony is the name by which they are universally known through our mountains. "Pika" is a book name of whose derivation I am ignorant, and Sir John Richardson, in the "Fauna Boreali-Americana, calls them the "Little Chief Hare". They are really very close relations of the rabbits, and no kin to the cony of the Bible except as belonging to the elass Mammalia. Colorado has two formsthe Colorado Cony, Ochotona saxatilis, and Figgins's Cony, o. s. figginsi.

These aninals are generally distributed through the mountains at the ligher altitudes, ranging usually from about 9,000 feet almost to the summits of the highest peaks, provided always that they have their favorite slide rock to live in, for they are seldom found away from it. Here they find innumerable cracks and crevices in which to make their homes, and in which they can take refuge from their enemies. Their food consists of plants of all sorts, which they gather from the hillsides by their homes, and which they store as "hay" for the winter. Sometimes they make real little haycocks, in a typical rounded heap, or again the hay is stored under llat rocks. One of their stacks found in New Mexico contained thirtylour different kinds of plants. The plants are gathered by biting off the stems and then, raking the ends of several into his mouth, the little haymaker starts for his stack dragging his plunder beside him. 
Conies are diurnal in habit, and when not feeding or making hay, spend much of their time sunning themselves on rocks near their nests. They have a high-pitched, squeaky note, quite penetrating, and uttered in

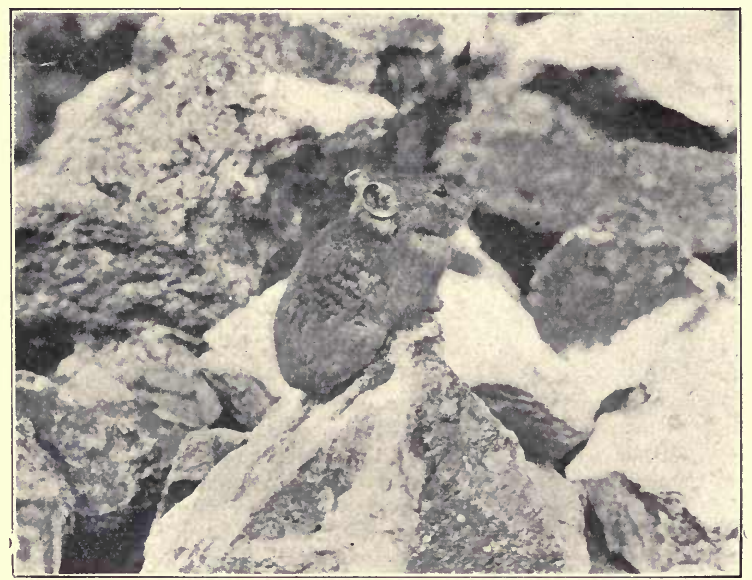

No. 18. Cony, or Pika, Ochotona saxatills.

a spasmodic fashion. I always think it sounds as though someone had squeezed the animal suddenly as one would a toy, making it squeak. Nelson renders it by the syllables "eh-eh". They have three or four young in a litter, born early in the summer. In winter they probably move about in the slide rock, and possibly just on top of it, under the snow, but it must be confessed that little is known about their winter habits. The coat is rather long and soft, very similar in texture to that of a rabbit, and in color is a mixture of blown, gray and black. The total length is about eight inches, with the tail practically wanting.

\section{RABBITS.}

Our rabbits divide naturally into two groups, one including the Jack Rabbits and the Snowshoe Rabbit, the other the Cottontails. The former are really Hares, belonging to the genus Lepus, and their young are born fully furred and with their eyes open; the latter belong to the genus Sylvilagus, and their young are born naked and blind, as is the case with our domestic rabbits. The Jack Rabbits divide again into two groups, the White-tails and Black-tails, and are found over most of the open parts of the state. The Black-tails are confined to the lower elevations, while the White-tails range even to above timberline on some of our highest mountains. There are two subspecies of each, the White-tailed Jack Rabbit, L. townsendi campanius, and the Western White-tailed Jack Rabbit, $\mathbf{L}$. townsendi townsendi; the Great Plains Jack Rabbit, L. californicus melanotis, and the Texas Jack Rabbit, L, c. texianus.

Living as they do in the open, the Jack Rabbits make their forms under protecting weeds or low bushes, usually, I think, where they can 
have a good outlook for possible enemies. Two or more litters are bor'n in a season, from three to five or six in a litter.

Though belonging to the same genus as the Jack Rabbits, the Snowshoe Rabbit (1. bairdi) has a very different habitat, living in the wood: or about brushy places in the mountains, but never in the open. It changes its coat according to the season, becoming white in winter. The White-tailed Jacks in the snowier parts of their range do the same, but do not become so completely white as the Snowshoes. This change takes place in October, and the return to the brown summer coat begins in April. The comparatively enormous

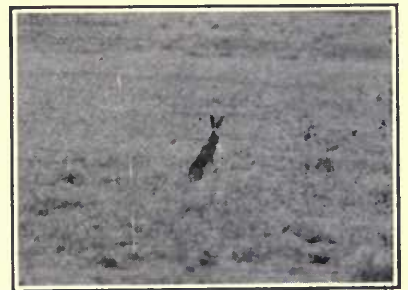

No. 19. White-tailed Jack Rabbit, I.puns campestris. hindfeet, with wide-spreading toes, make excellent snowshoes, holding! up the animal in the snow. The hindfoot is as long as that of the much larger Jack Rabbit, and makes a larger track in the snow.

\section{CO'TTONTAILS.}

Colorado is blessed with five species and subspecies of Cottontails, as follows: the Nebraska Cottontail, Sylvilagns floridanus similis; the Rocky Mountain Cottontail, s. nuttalli pinetis; the Black Hills Cottontail, S. n. grangeri; the Wyoming or Bailey's Cottontail, s. auduboni baileyi; and the Colorado Cottontail. s. a. Warreni. These various forms occupy separate, though sometimes overlapping ranges. The Nebraska Cottontail is confined to the northeastern part of the state, ranging back toward the

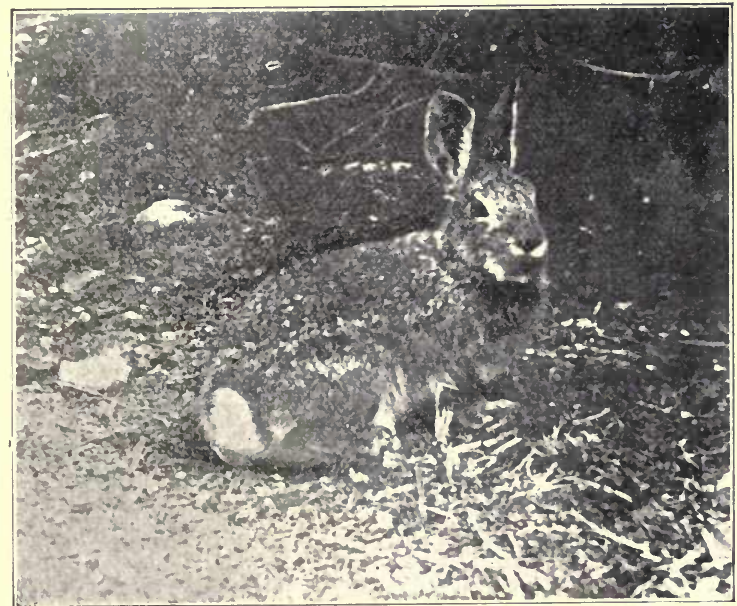

No. 20. Rocky Mountain Cottontail, sylvilaus n. pinetis. 
foothills, as at Arvada and Littleton, and occupying the country in common with the Wyoming Cottontail, but with this essential difference in habits-that the Nebraska prefers to live in the brush along the streams,

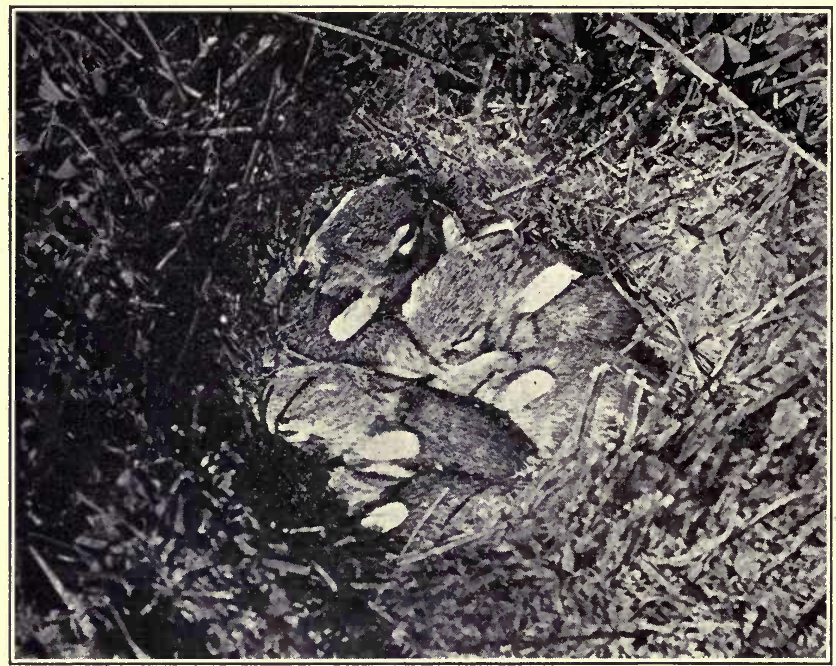

No. 21. Young Cottontails in nest in alfalfa field. Photograph from Colorado Agricultural College, through W. L. Burnett.

while the Wyoming lives on the more open prairie, about the sage and rabbit brush. In other respects the habits of all these animals are similar. They occupy almost all kinds of habitats, they live both in burrows and in forms, and the young are born naked and blind in nests lined with fur from the mothers' breasts. In some parts of the mountains the Rocky Mountain Cottontail goes nearly to timberline. Ledges of rock with plenty of cracks and holes are favorite dwelling places for all the species. On the plains cottontails are often found about the prairie dog towns, living in abandened holes. 


\section{IBIBIIOGRAPHY.}

I have divided the following brief bibliography into two parts: The first includes publications of a more technical character, in all of which, however, will be found interesting data on the habits and life histories of the groups treated. The second part includes papers pertaining to the economic status and habits of the animals:

\section{'TECHNICAI, PAPEIR.}

Hailey, V. Revision of the American Voles of the Genus vicrotus. North American Fauna No. 17. 1900.

Goldman, E. A. Revision of the Wood Rats of the Genus Neatomn. North American Fauna No. 31. 1910.

Hollister, N. A Systematic Synopsis of the Muskrats. North American Fauna No. 32. 1911

Hollister, N. A Systematic Account of the Prairie Dogs. North American Fauna No. 40.1916.

Hollister, N. A Systematie Aceount of the Grasshopper Mice. Proceedings U. S. National Museum. Vol. 47, I'p. 427-489. 1914.

Howell, A. H. Revision of the skunks of the Genus ('hineha (vephitis). North American Fauna No, 20.1901.

Howell, A. H. Revision of the Skunks of the Genus sullogule. North American Fauna No. 26.1906.

Howell, A. H. Revision of the American Harvest Mice. (Genus Rheithrodontoms.) North American Fauna No, 36.1914.

Howell, A. H. Revision of the Ameriean Marmots. North American Fauna No. 37. 1915

Jackson, H. H. T. A Review of the American Noles. North American Fauna No. 38. 1915

Nelson. E. W. The Rabbits of North Ameriea. North Ameriean Fauna. No. 29. 1909.

Osgood, W. H. Revision of the Pocket Mice of the Genus Perognathus. North American Fauna No. 18.1900.

Ospood, W. H. Revision of the North Ameriean Genus leromysus. North American Fauna No. 28. 1909.

Preble, W. A. Revision of the Jumping Mice of the Genus Zaums. North American Fauna No. 15 . 1899 .

\section{O'THEIR I'A I'PIR:}

Burnett, W. L. Report on P'rairie Dog Investigations in Colorado. Agricultural Collewe Cireular 8 . 1913.

Burnett, W. L. The Prairie Dog Situation in Colorado. Agricultural College ('ireular 17. 1915.

IBurnett, W. L. Rodents of Colorado in Their Economic Relations. Agrieultural College Cireular 25.1918

IBunct. W. L. Meadow Mice (Mierotus). Asricultural College Circular 18. 1916 .

Lantz, I). E. Meadow Mice in Relation to Amriculture. Year Book of Department of Asriculture. 1905.

Lantz, D. W. An Economic Study of Field Mice (Genus vicrotus). Biologieal Survey liulletin No. 31.1907.

Lantz, D. 1). The Rabbit as a Farm and Orehard Pest. Year Book of Department of Acriculture. 1907.

Lantz, D. E. The Muskrat. Farmers' Bulletin 396. Department of Agrieulture. 1910 .

Lantz, D. E. The Muskrat as a Fur Bearer. Farmers' Bulletin 869, Department of Africulture. 1917 .

Lantz. D. E. Eeonomic Value of North American Skunks. Farmers' Bulletin 587 , Department of Agrieulture. 1914 .

Lantz, D. E. Field Mice as Farm and Orehard Pests. Farmers Bulletin 587. Department of Asiculture. 1915.

Merriam. C. H. The Prajie Dog of the Great Plains. Year Book of Department of Agrieulture. 1901.

Warren, E. R. The Manmals of Colorado. Putnam, New York. 1910. 




$$
\begin{aligned}
& \text { Qh } \\
& 719 \\
& \text { C6 } \\
& \text { W25 }
\end{aligned}
$$


UC SOUTHERN REGIONAL LIBRARY FACILITY

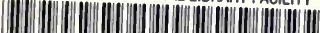

AA

AA 0012974077

THE LIBRARY

UNIVERSITY OF CALIFORNIA

Santa Barbara

THIS BOOK IS DUE ON THE LAST DATE STAMPED BELOW. 
